medRxiv preprint doi: https://doi.org/10.1101/2021.04.29.21256340; this version posted May 4, 2021. The copyright holder for this preprint (which was not certified by peer review) is the author/funder, who has granted medRxiv a license to display the preprint in perpetuity. All rights reserved. No reuse allowed without permission.

\title{
Germline RUNX1 Variation and Predisposition to Childhood Acute Lymphoblastic
}

\section{Leukemia}

3 Yizhen Li, PhD', , Meenakshi Devidas, $\mathrm{PhD}^{2}$, Wentao Yang, $\mathrm{PhD}^{1}$, Stuart S. Winter, MD ${ }^{3}$, Wenjian

4 Yang, $\mathrm{PhD}^{1}$, Kimberly P. Dunsmore, $\mathrm{MD}^{4}$, Colton Smith, $\mathrm{PhD}^{1}$, Maoxiang Qian, $\mathrm{PhD}^{5}$, Xujie Zhao, $5 \quad \mathrm{MS}^{1}$, Ranran Zhang, MS¹, Julie M. Gastier-Foster, $\mathrm{PhD}^{6}$, Elizabeth A. Raetz, MD , William L. 6 Carroll, MD , Chunliang Li, PhD ${ }^{8}$, Paul P. Liu ${ }^{9}$, Karen R. Rabin, MD, PhD ${ }^{10}$, Takaomi Sanda ${ }^{11,12}$, 7 Charles G. Mullighan, MBBS, MD ${ }^{13}$, Kim E. Nichols, MD ${ }^{14}$, William E. Evans, PharmD ${ }^{1,15}$, Ching8 Hon Pui, MD ${ }^{14,15}$, Stephen P. Hunger, MD ${ }^{16}$, David T. Teachey ${ }^{17}$, MD, Mary V. Relling, PharmD ${ }^{1,14}$, 9 Mignon L. Loh, MD ${ }^{18}$, Jun J. Yang, $\mathrm{PhD}^{1,}$ 14, 15 f

$10{ }^{1}$ Department of Pharmaceutical Sciences, St. Jude Children's Research Hospital, Memphis, TN, 112 'Department of Global Pediatric Medicine, St. Jude Children's Research Hospital, Memphis, TN, $12{ }^{3}$ Children's Minnesota Research Institute, Children's Minnesota, Minneapolis, MN, ${ }^{4}$ Children's 13 Hematology and Oncology, Carilion Clinic and Virginia Tech Carilion School of Medicine, 14 Roanoke, VA, ${ }^{5}$ Children's Hospital and Institutes of Biomedical Sciences, Fudan University, 15 Shanghai, China, ${ }^{6}$ Baylor College of Medicine and Texas Children's Hospital, Houston, TX, $16{ }^{7}$ Division of Pediatric Hematology and Oncology, Perlmutter Cancer Center, New York University 17 Langone Health, New York, ${ }^{8}$ Tumor Cell Biology, St. Jude Children's Research Hospital, Memphis, $18 T N,{ }^{9}$ Oncogenesis and Development Section, National Human Genome Research Institute, 19 National Institutes of Health, Bethesda, MD, USA, ${ }^{10}$ Texas Children's Cancer and Hematology 20 Centers, Baylor College of Medicine, Houston, TX, ${ }^{11}$ Cancer Science Institute of Singapore, 21 National University of Singapore, Singapore, ${ }^{12}$ Department of Medicine, Yong Loo Lin School of 22 Medicine, National University of Singapore, Singapore, ${ }^{13}$ Department of Pathology, St. Jude 23 Children's Research Hospital, Memphis, TN, ${ }^{14}$ Department of Oncology, St. Jude Children's 24 Research Hospital, Memphis, TN, ${ }^{15}$ Hematological Malignancies Program, St. Jude Children's 25 Research Hospital, Memphis, TN, ${ }^{16}$ Department of Pediatrics and Center for Childhood Cancer 26 Research, Children's Hospital of Philadelphia and the Perelman School of Medicine at the 27 University of Pennsylvania, Philadelphia, PA, ${ }^{17}$ Division of Oncology, Department of Pediatrics, 28 Center for Childhood Cancer Research, Children's Hospital of Philadelphia and Perelman School 29 of Medicine, University of Pennsylvania, Philadelphia, PA, ${ }^{18}$ Department of Pediatrics, Benioff 30 Children's Hospital and the Helen Diller Family Comprehensive Cancer Center, University of 31 California San Francisco, San Francisco, CA 
medRxiv preprint doi: https://doi.org/10.1101/2021.04.29.21256340; this version posted May 4, 2021. The copyright holder for this preprint (which was not certified by peer review) is the author/funder, who has granted medRxiv a license to display the preprint in perpetuity.

All rights reserved. No reuse allowed without permission.

\section{Abstract}

34 RUNX1 is a transcription factor critical for definitive hematopoiesis and genetic alterations in

35 RUNX1 have been implicated in both benign and malignant blood disorders, particularly of the

36 megakaryocyte and myeloid lineages. Somatic RUNX1 mutations are reported in B- and T-cell

37 acute lymphoblastic leukemia (B-ALL and T-ALL), but germline genetic variation of $R U N X 1$ in

38 these lymphoid malignancies have not been comprehensively investigated. Sequencing 4,836

39 children with B-ALL and 1,354 cases of T-ALL, we identified 31 and 18 unique germline RUNX1

40 variants in these two ALL subtypes, respectively. RUNX1 variants in B-ALL were predicted to

41 have minimal impact. By contrast, $54.5 \%$ of variants in T-ALL result in complete or partial loss of

42 RUNX1 activity as a transcription activator in vitro, with dominant negative effects for 4 variants.

43 Ectopic expression of dominant negative deleterious RUNX1 variants in human CD34+ cells

44 repressed differentiation into erythroid, megakaryocytes, and $\mathrm{T}$ cells, while promoting

45 differentiation towards myeloid cells. We then performed chromatin immunoprecipitation profiling

46 in isogenic T-ALL models with variants introduced by genome editing of endogenous $R U N X 1$. We

47 observed highly distinctive patterns of DNA binding and target genomic loci by RUNX1 proteins

48 encoded by the truncating vs missense variants. The p.G365R RUNX1 variant resulted in a novel

49 methylation site in RUNX1 and alteration in its interaction with CBF $\beta$. Further whole genome

50 sequencing showed that JAK3 mutation was the most frequent somatic genomic abnormality in

51 T-ALL with germline RUNX1 variants. Consistently, co-introduction of $R U N X 1$ variant and JAK3

52 mutation in hematopoietic stem and progenitor cells in mouse gave rise to T-ALL with early T-cell

53 precursor phenotype in vivo, compared to thymic T-ALL seen in mice with JAK3 mutation alone.

54 Taken together, these results indicated that $R U N X 1$ is an important predisposition gene for ALL,

55 especially in T-ALL and also pointed to novel biology of RUNX1-mediated leukemogenesis in the

56 lymphoid lineages. 
medRxiv preprint doi: https://doi.org/10.1101/2021.04.29.21256340; this version posted May 4, 2021. The copyright holder for this preprint (which was not certified by peer review) is the author/funder, who has granted medRxiv a license to display the preprint in perpetuity.

All rights reserved. No reuse allowed without permission.

\section{Introduction}

59 Acute lymphoid leukemia (ALL) is the most common cancer in children. The exact cause of ALL

60 is incompletely understood, although somatic genomic abnormalities are well documented

61 affecting a wide range of signaling pathways. There is also growing evidence of inherited

62 susceptibility to ALL. For example, common genetic polymorphisms in genes such as IKZF1(1),

$63 A R I D 5 B(2), \operatorname{CDKN} 2 A(3), \operatorname{GATA3}(4,5), \operatorname{CEBPE}(6)$, and $P I P 4 K 2 A(7)$ are associated with the risk

64 of ALL in an age- and subtype-dependent manner. On the other hand, rare germline variants have

65 been linked to familial predisposition to childhood ALL, and collectively about $5 \%$ of sporadic ALL

66 cases harbor pathogenic variants in TP53(8), ETV6(9), and IKZF1(1). These findings point to a

67 strong genetic basis of inter-individual variability in ALL risk.

68 The RUNX1 protein plays key roles in definitive hematopoiesis (10). RUNX1 functions as a

69 transcription factor by forming a heterodimer with core binding factor $\beta$ (CBF $\beta$ ). RUNX1 consists

70 of a Runt homology domain (RHD) responsible for DNA binding and cofactor interaction (11) and

71 the C-terminal transcriptional activation domain (TAD) that recruits co-activators and activates the

72 expression of RUNX1 target genes (12). RUNX1 germline variants are associated with familial

73 platelet disorder (FPD). Many patients with FPD develop leukemia later in life, predominately

74 acute myeloid leukemia (AML) and myelodysplastic syndrome (MDS) (13-16). Somatic RUNX1

75 mutations, most of which occur in the RHD and TAD, have been identified in both B- and T-

$76 \mathrm{ALL}(17)$. RUNX1 mutation is related to poor prognosis in T-ALL(17). Although somatic and

77 germline RUNX1 variants associated with ALL have been reported, their pattern, prevalence, and

78 functional consequences in B-ALL and T-ALL have not been comprehensively investigated.

79 Here we report results from targeted germline sequencing of 6,190 children with B- or T-ALL

80 enrolled in frontline Children's Oncology Group (COG) and St. Jude Children's Research

81 Hospital (St. Jude) ALL trials. We observed a lineage-specific pattern of germline variation in the

82 RUNX1 gene, with deleterious variants exclusively present in T-ALL patients. Furthermore, we

83 experimentally characterized $R U N X 1$ variants for their effects on transcription factor activity, 
medRxiv preprint doi: https://doi.org/10.1101/2021.04.29.21256340; this version posted May 4, 2021. The copyright holder for this preprint (which was not certified by peer review) is the author/funder, who has granted medRxiv a license to display the preprint in perpetuity.

All rights reserved. No reuse allowed without permission.

84 subcellular localization, cofactor interaction, in vitro hematopoiesis, and genome wide RUNX1

85 binding profile. Finally, we examined the somatic genomic landscape of T-ALL arising from

86 RUNX1 germline variants and modeled RUNX1-mediated leukemogenesis in mouse models. 
medRxiv preprint doi: https://doi.org/10.1101/2021.04.29.21256340; this version posted May 4, 2021. The copyright holder for this preprint (which was not certified by peer review) is the author/funder, who has granted medRxiv a license to display the preprint in perpetuity.

All rights reserved. No reuse allowed without permission.

\section{Results}

\section{Identification of germline $R U N X 1$ variants in pediatric ALL}

89 To comprehensively characterize inherited $R U N X 1$ variations in $A L L$, we performed targeted

90 sequencing in germline DNA of 4,836 patients with newly diagnosed B-ALL and 1,354 patients

91 with T-ALL enrolled on COG and SJCRH frontline trials (Figure 1A and Table 1). We identified

9231 unique variants in 61 B-ALL cases and 18 unique variants in 26 T-ALL cases. Seven of these

93 variants were found in both B- and T-ALL (Figure 1A and Table 1).

94 Of the 31 variants in B-ALL, 6 were not observed in the general population (Genome

95 Aggregation database, gnomAD, $n=15,496)$, 18 were rare with a maximum allele frequency of

$960.00122 \%$, and the remaining 7 were considered common variants with allele frequency $>$

$970.01 \%$ (Figure 1A and Table 1). All the variants in B-ALL except one were missense, most of

98 which are in the C-terminus distal to the DNA binding runt-homology domain (RHD, Figure 1B).

99 Of the 18 variants in T-ALL cases, 8 were absent in the gnomAD dataset, 5 were rare with a

100 maximum allele frequency of $0.00239 \%$, and the remaining 5 were common variants (Figure 1A

101 and Table 1). $27.8 \%$ of variants identified in T-ALL were frameshift or nonsense, including

102 p.K117* and p.S141fs which truncated both the RHD and the transcription activation domain

103 (TAD, Figures 1B and S1) and p.Q213fs, p.R232fs, and p.Y287* that resulted in the loss of

104 TAD only (Figure S1). Seven missense and 1 in-frame deletion variants in T-ALL were

105 distributed across $R U N X 1$. This pattern of variant distribution is significantly different from

106 RUNX1 germline variants in familial platelet disorder with associated myeloid malignancy

107 (Figure 1C)(18), in which the majority of missense variants are localized in the DNA-binding

108 domain (RHD).

109 Effects of $\boldsymbol{R} U \boldsymbol{N X} 1$ variants on transcriptional regulation, cellular localization, and protein-

110 protein interaction

111 To understand how germline $R U N X 1$ variants affect gene function, we first examined their 112 transcription activator activity using the luciferase reporter assay in Hela cells. With SPI1 as the 
medRxiv preprint doi: https://doi.org/10.1101/2021.04.29.21256340; this version posted May 4, 2021. The copyright holder for this preprint (which was not certified by peer review) is the author/funder, who has granted medRxiv a license to display the preprint in perpetuity.

All rights reserved. No reuse allowed without permission.

113 RUNX1 target gene (19), none of the germline variants identified in B-ALL showed a significant

114 impact on reporter gene transcription compared to the wildtype protein and therefore were not

115 studied further (Figure 2A). Among RUNX1 alleles seen in T-ALL, all frameshift and nonsense

116 variants (p.K117*, p.S141fs, p.S213fs, p.R232fs, and p.Y287*) and also missense variant G365R

117 caused significant reduction of RUNX1 activity in this assay (Figure 2B). To further characterize

118 these RUNX1 variants in a more relevant cellular context, we engineered the Jurkat T-ALL cell

119 line in which each $R U N X 1$ variant of interest was individually inserted into the safe harbor AAVS1

120 locus (Figure S2)(20) and a GFP tag was added to the C-terminus of RUNX1 target gene

121 GZMA(21) (Figure 2C and S3). Using this model system, RUNX1 transactivation activity could

122 be directly measured as the GFP intensity in RUNX1 variants knock-in cells, in the presence of

123 endogenous $R U N X 1$ (Figure 2D). As shown in Figure 2E, the introduction of WT RUNX1 as well

124 as most missense variants (p.N153Y, p.T246M, p.A329T, p.P359R, and p.M418V) led to robust

125 GFP signals relative to cells with no RUNX1 insertion at the AAVS locus, confirming wildtype like

126 transcription activator activity. By contrast, cells with $\mathrm{K} 117^{*}$ and $\mathrm{S} 141 \mathrm{fs}$ showed only baseline

127 GFP signals, indicating complete loss of RUNX1 function. Insertion of the p.Q213fs, p.R232fs,

128 p.Y287*, and p.G365R variants resulted in the lowest GFP intensity, suggesting these variants

129 not only lost their transcription activator activity but also repressed endogenous RUNX1 in a

130 plausibly dominant-negative manner.

131 We next analyzed subcellular localization and CBF $\beta$ cofactor interaction of all deleterious variants,

132 including p.K117*, p.S141fs, p.Q213fs, p.R232fs, p.Y287*, and p.G365R (Figure S1).

133 Fluorescence microscopy of HEK293T cells ectopically expressing RUNX1 variants showed that

134 p.K117* and p.S141fs proteins were mis-localized to the cytoplasm, whereas p.Q213fs, p.R232fs,

135 p.Y287*, p.G365R proteins remained in the nucleus (Figure 2F). In co-immunoprecipitation assay,

136 p.K117* and p.S141fs variant proteins were no longer associated with CBF $\beta$ most likely due to

137 the absence of RHD, whereas all the other variants retained the ability to interact with this co-

138 factor (Figure 2G). 
medRxiv preprint doi: https://doi.org/10.1101/2021.04.29.21256340; this version posted May 4, 2021. The copyright holder for this preprint (which was not certified by peer review) is the author/funder, who has granted medRxiv a license to display the preprint in perpetuity.

All rights reserved. No reuse allowed without permission.

Effects of $R U N X 1$ variants on the differentiation and proliferation of human cord blood

141 We next sought to examine the effects of $R U N X 1$ variants on hematopoietic differentiation in vitro

142 using human cord blood CD34+ cell as the model system. Because p.K117 and p.S141fs simply

143 resulted in complete loss of function with no dominant negative effects, we chose not to further

144 characterize them. For the remaining deleterious variants, we selected p.R232fs, p.Y287* and

145 p.G365R to represent frameshift, nonsense, and missense variants, respectively (Figure S4).

146 RUNX1 variants were ectopically expressed in human CD34+ cells which were then subjected to

147 differentiation, proliferation, and apoptosis assays in vitro (Figure 3A).

148 In colony formation assays conditioned for erythroid and myeloid progenitor cell growth, the expression of p.R232fs, p.Y287*, and p.G365R significantly repressed burst-forming unit erythroid 150 (BFU-E) and increased colony-forming unit granulocyte-macrophage (CFU-GM) colonies 151 compared to CD34+ cells transduced with WT RUNX1 (Figure 3B). The immunophenotype of

152 these progenitor cells were also confirmed by flow cytometry (Figure S5A). Long-term culture 153 showed that the RUNX1 variant-transduced CD34+ cells proliferated faster with concomitant 154 reduction in apoptosis, compared to WT RUNX1 transduced cells (Figure 3C-D and S5B).

155 With culture conditions for megakaryocyte differentiation, expression of RUNX1 variants 156 consistently resulted in a significant reduction of CD41a+/CD42b+ population compared to WT

157 (Figure 3E). These RUNX1 variants also significantly repressed the generation of CD5+/CD7+ T 158 cells from the CD34+ population (Figure 3F). Collectively, these results suggested that RUNX1 159 variants promoted myeloid differentiation while repressing megakaryocyte and T-cell 160 differentiation in vitro.

161 RUNX1 variants have highly distinctive patterns of DNA binding and are associated with 162 altered post-translational modifications

163 To understand the molecular effects of $R U N X 1$ variants, we comprehensively profiled RUNX1 164 binding across the genome using chromatin immunoprecipitation-sequencing (ChIP-seq). We first 
medRxiv preprint doi: https://doi.org/10.1101/2021.04.29.21256340; this version posted May 4, 2021. The copyright holder for this preprint (which was not certified by peer review) is the author/funder, who has granted medRxiv a license to display the preprint in perpetuity.

All rights reserved. No reuse allowed without permission.

165 engineered three isogenic Jurkat cell lines in which each of the three $R U N X 1$ variants (p.R232fs,

166 p.Y287*, and p.G365R) was individually knocked-in at the endogenous locus in a hemizygous

167 fashion to represent heterozygous genotype seen in patients (Figure 4A and 4B). In these

168 models, we introduced the HA tag and TY1 epitope tags at the 3' end of the coding exon on the

169 variant and WT RUNX1 alleles, respectively (Figure S6-S10). This enabled us to separately

170 profile variant or WT RUNX1 binding using HA or TY1 antibodies (Figure S9C-D and S10C-D).

171 We also generate two single clones, in which both allele were wildtype $R U N X 1$, but tagged with

172 HA and TY1 seperately (Figure S8 and S10).

173 ChIP-seq showed that all three variants have a largely overlapping binding profile as WT RUNX1

174 in T-ALL genome (Figure 4C). However, the C-terminal truncating variants p.R232fs and p.Y287*

175 exhibited a much similar binding pattern compared with missense p.G365R variant and wildtype

176 RUNX1 (Figure 4D and S11), as evidenced by the pearson correlation coefficient of ChIP-seq

177 signals. Even though these variant proteins maintained the DNA binding domain, their DNA

178 binding preference was different from wildtype or full-length missense mutation RUNX1.

179 Interestingly, the p.G365R variant gave rise to a novel methylation site in RUNX1, with mono- or

180 di-methylation of the arginine residue confirmed by mass spectrometry and Western blot analysis

181 (Figure 4E and 4F). Immunoprecipitation-mass spectrometry results suggested that RUNX1

182 protein methylation at this site may disrupt its interaction with TUBB family proteins (TUBB2A,

183 TUBB2B, TUBB4B, TUBB5, TUB8, et al.) and heat shock proteins, but with an increase of CBF

184 binding (Table S1).

185 Somatic genomic abnormalities in T-ALL with germline $R U N X 1$ variants

186 To characterize the somatic genomic landscape of T-ALL with germline RUNX1 variants, we 187 analyzed whole genome seq of six cases with p.K117*, p.S141fs, p.Q213fs, p.R232fs, p.Y287*, 188 and p.G365R variants, which were contrasted with 263 T-ALL with somatic mutations in RUNX1 189 or WT genotype (22). Five of six T-ALL (83.3\%) with germline RUNX1 variants had a somatic 190 JAK3 mutation, significantly higher compared to the frequency of JAK3 mutation percentage in T- 
medRxiv preprint doi: https://doi.org/10.1101/2021.04.29.21256340; this version posted May 4, 2021. The copyright holder for this preprint (which was not certified by peer review) is the author/funder, who has granted medRxiv a license to display the preprint in perpetuity.

All rights reserved. No reuse allowed without permission.

191 ALL cases without germline variants in $\operatorname{RUNX1}\left(7.6 \%\right.$, p-value $\left.=2.59 \times 10^{-5}\right)(22)$ or T-ALL cases

192 with somatic mutations in $\operatorname{RUNX1}(27.3 \%$, $\mathrm{p}$-value $=0.05)$ (Figure 5A). JAK3 mutations in T-ALL

193 cases with germline RUNX1 variants were located in either the pseudo-kinase domain (M511I

194 and R657Q) or in the kinase domain (L950V, Figure S12 and Tables S2 and S3). Of interest,

195 the patient with a germline $R U N X 1-\mathrm{R} 232 \mathrm{fs}$ variant also subsequently acquired a somatic $R U N X 1$

196 mutation (R169_E5splice_region).

197 We also performed RNA-seq of T-ALL with germline RUNX1 variants and compared the 198 expression profile with cases with germline $R U N X 1$ variants, somatic RUNX1 mutations or WT $199 R U N X 1(\mathrm{~N}=4,11$ and 252, respectively). Based on hierarchical clustering of global expression 200 profile, RUNX1-variant cases (either germline or somatic) consistently clustered with T-ALL with 201 early T-cell precursor immunophenotype (ETP) or near-ETP cases (Figure 5B). These results 202 are consistent with previous reports of the preponderance of $R U N X 1$ variants in ETP T-ALL (23).

203 RUNX1 and JAK3 mutation-induced ETP phenotype in murine bone marrow 204 transplantation model

205 To model RUNX1-related T-ALL leukemogenesis, especially in conjunction with somatic JAK3 206 mutation, we introduced different combinations of $R U N X 1$ and JAK3 mutations (RUNX1 ${ }^{R 232 f s}$ and 207 JAK3 $\left.{ }^{M 511}\right)$ into mouse hematopoietic progenitor cells (Lin-/Sca-1+/C-Kit ${ }^{+}$) and monitored leukemia 208 development in vivo after transplantation. We hereafter refer to recipient mice with LSK cells

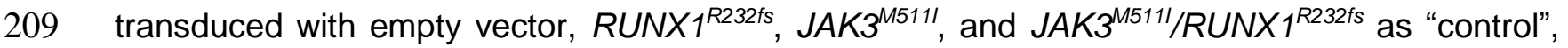

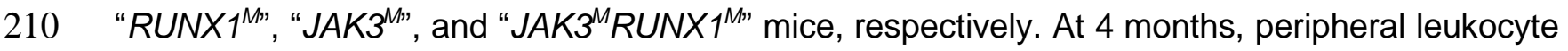
211 counts of $J A K 3^{\mathrm{M}}$ and $J A K 3^{M} R U N X 1^{M}$ mice $(41.78 \pm 44.3 \mathrm{E} 3$ cells $/ \mu \mathrm{L}$ and $14.93 \pm 3.42 \mathrm{E} 3 \mathrm{cells} / \mu \mathrm{L}$ 212 respectively) were significantly higher than control mice $(8.84 \pm 2.00 \mathrm{cells} / \mu \mathrm{L})$, and the lowest 213 peripheral leukocyte counts were seen in $R U N X 1^{M}$ mice $(6.10 \pm 2.03$ cells/ $\mu \mathrm{L}$, Figure S13A $)$. Flow 214 cytometry analysis at this time point showed a significant increase of CD8+ T cells in JAK3 ${ }^{\mathrm{M}}$ mice 215 (Figure S13B and C), compared with control mice. By contrast, JAK3 $3^{\mathrm{M}} R U N X 1^{\mathrm{M}}$ mice showed an 
medRxiv preprint doi: https://doi.org/10.1101/2021.04.29.21256340; this version posted May 4, 2021. The copyright holder for this preprint (which was not certified by peer review) is the author/funder, who has granted medRxiv a license to display the preprint in perpetuity.

All rights reserved. No reuse allowed without permission.

216 increase in Mac1+ population and lower T cell population, suggesting an outgrowth of cells with

217 ETP immunophenotype (Figure S13B and C).

218 At 6 to 10 months after transplantation, both $J A K 3^{\mathrm{M}} R U N X 1^{\mathrm{M}}$ and $J A K 3^{\mathrm{M}}$ mice developed overt

219 leukemia presented with leukocytosis and splenomegaly, with $66.7 \%$ and $100 \%$ mice developed

220 leukemia, respectively (Figure 5 C-E and S14). The thymus of $J A K 3^{\mathrm{M}} R U N X 1^{\mathrm{M}}$ mice showed a

221 significantly increase of CD4-CD8- (DN) T cells, particularly DN1 cells, as compared with JAK3 ${ }^{\mathrm{M}}$

222 mice (Figure 5F-G). Circulating leukemic cells of $J A K 3^{\mathrm{M}} R U N X 1^{\mathrm{M}}$ mice showed a markedly higher

223 Mac1 + population, but lower lymphoid surface marker as compared with JAK3 ${ }^{\mathrm{M}}$ mice (Figure 5H).

224 Also, flow analysis of spleen and bone marrow showed a similar leukemia immunophenotype as

225 peripheral blood (Figure $5 \mathrm{H}$ ). These results indicate that $J A K 3^{M} R U N X 1^{M}$ induced the ETP-ALL

226 phenotype in vivo. There was also a trend for higher Mac1+ cells with lower level of CD3+ cells

227 in the peripheral blood of $R U N X 1^{\mathrm{M}}$ mice but they never developed leukemia within this timeframe

228 (Figure S13).

229 
medRxiv preprint doi: https://doi.org/10.1101/2021.04.29.21256340; this version posted May 4, 2021. The copyright holder for this preprint (which was not certified by peer review) is the author/funder, who has granted medRxiv a license to display the preprint in perpetuity.

All rights reserved. No reuse allowed without permission.

\section{Discussion}

231 RUNX1 plays significant roles in definitive hematopoiesis by regulating the differentiation of

232 myeloid, megakaryocyte, and lymphoid lineages. In this study, we comprehensively investigated

233 RUNX1 variants in germline ALL samples from patients and identified highly deleterious germline

234 RUNX1 variants in T-ALL cases, most of which were frameshift or nonsense variations. By

235 multilayer functional experiments and comprehensive epigenomic and genomic profiling analyses, we systematically characterized $R U N X 1$ variant functions and identified JAK3 mutations as

237 predominant co-operating somatic lesions in T-ALL. Furthermore, RUNX1 variant, in conjunction 238 with mutant JAK3, directly gave rise to ETP-ALL in vivo. These findings advance our 239 understanding of the role of $R U N X 1$ in the predisposition to childhood ALL.

240 As a crucial transcription factor that regulates the hematopoietic differentiation of multiple lineages,

$241 R U N X 1$ is one of the most frequent target genes of chromosomal translocation, mutation, and 242 copy number alteration in different hematopoietic diseases and leukemia. RUNX1 germline 243 variants are associated with familial platelet disorder with associated myeloid malignancy 244 (FPDMM, OMIM \#601399), also known as FPD or FPD/AML (13, 14, 16, 24). Although most 245 patients with FPD progress to myeloid malignancies, ALL has been reported in a minority of cases $246(14,15)$. In MDS and AML with germline RUNX1 variants, somatic RUNX1 mutations are the most

247 frequently observed genomic alteration, suggesting they are one of the cooperating events for 248 leukemia progression $(18,25)$. Other studies identified somatic mutations in CDC25C, GATA2, 249 BCOR, PHF6, JAK2, DNMT3A, TET, ASXL1 albeit with lower frequencies $(18,25,26)$. By contrast, 250 we identified JAK3 mutations as the predominant co-occurring event with RUNX1 germline 251 variants in T-ALL, which consistently drove an ETP phenotype in patients and in mouse models. 252 Therefore, we postulate that while germline RUNX1 variants disrupt normal hematopoiesis and 253 generally increase the risk of leukemia, the lineage specification of these hematological 254 malignancies is mostly dictated by secondary mutations acquired later in life. 
medRxiv preprint doi: https://doi.org/10.1101/2021.04.29.21256340; this version posted May 4, 2021. The copyright holder for this preprint (which was not certified by peer review) is the author/funder, who has granted medRxiv a license to display the preprint in perpetuity.

All rights reserved. No reuse allowed without permission.

Activating JAK3 mutations have been reported in T-ALL (23). In vivo studies using a murine bone marrow transplantation model showed that JAK3 mutations in the pseudo-kinase domain caused T-cell lymphoproliferative disease that progressed to T-ALL, mainly by increasing the CD8+ cell population $(27,28)$. This is in line with our observation that $J A K 3^{\mathrm{M}}$ mice exhibited a significant accumulation of CD8+ cells in thymus, peripheral blood, spleen, and bone marrow. However, $J A K 3^{\mathrm{M}} R U N X 1^{\mathrm{M}}$ mouse developed lymphoid leukemia with a completely distinctive phenotype which recapitulated human ETP T- ALL features similar to previous reported ETP-ALL mouse models (e.g., circulating leukemic cells expressed the myeloid cell marker Mac1, but not the 263 lymphoid markers CD8/CD3)(29, 30). Also, the CD4-CD8- (DN), especially DN1 population was 264 particularly enriched in thymocytes from $J A K 3^{\mathrm{M}} R U N X 1^{\mathrm{M}}$ mice, as compared with $J A K 3^{\mathrm{M}}$ mice. 265 Alongside genomic findings in T-ALL patients, these in vivo experiments indicate that RUNX1 266 dominant-negative variants plus JAK3-activating mutations most likely result in the ETP T-ALL.

267 A recent study by Brown et al. comprehensively described the genomic landscape of $R U N X 1$ related FPD and myeloid malignancy from 130 families (18). In this cohort, missense and truncating germline $R U N X 1$ variants were equally represented. While truncating variants occurred in both the RUNT domain and the activation domain, missense variants were largely restricted to

271 the DNA-binding RUNT domain. This pattern is significantly different from that in the lymphoid 272 malignancies as described herein. In T-ALL, deleterious RUNX1 variants were predominantly 273 nonsense or frameshift and the only missense variant resided in the activation domain. 274 Unfortunately, we do not have family history for children with T-ALL carrying RUNX1 germline 275 variants, and therefore cannot ascertain the exact penetrance on leukemia or FPD. However, 276 given the profound effects on RUNX1 activity and a range of phenotypes in vitro and in vivo, these 277 variants are likely to be pathogenic. In fact, the $\mathrm{Y}^{287^{*}}$ variant seen in our T-ALL cohort has been 278 previously linked to FPD and functional characterization indicated that this variant causes 279 defective megakaryocyte differentiation in the iPSC model (31). In B-ALL, almost all variants were 280 missense and localized outside of RUNT domain, likely with little effects on RUNX1 activity. 
medRxiv preprint doi: https://doi.org/10.1101/2021.04.29.21256340; this version posted May 4, 2021. The copyright holder for this preprint (which was not certified by peer review) is the author/funder, who has granted medRxiv a license to display the preprint in perpetuity.

All rights reserved. No reuse allowed without permission.

281 Although these variants showed little effects on RUNX1 transcriptional activity level, some of them

282 were predicted to be damaging variants by polyphen2 and SIFT (Table 1). More comprehensive

283 functional assays might be needed to definitively determine the effects of these variants.

284 Genome-wide patterns of RUNX1 binding have been investigated extensively using ChIP-seq 285 assays $(21,32,33)$, but there is a paucity of studies directly examining target genes of variant 286 RUNX1. When this was attempted in the past, variant RUNX1 was either ectopically expressed 287 in iPSC or cord blood CD34+ cells, raising the possibility of false positives due to artificially high 288 levels of RUNX1(34). This is also hindered by the lack of antibodies that specifically recognize 289 wildtype but not variant RUNX1. To overcome these issues, we engineered Jurkat cells with 290 heterozygous knock-in of RUNX1 variants (p.R232fs/WT, p.Y287* WT, and p.G365R/WT) using 291 the CHASE-KI method (35). In this model, we also introduced the HA and TY1 epitope tags at the 292 3' end of the coding exon on the variant and WT RUNX1 allele, respectively. Our model 293 recapitulated $R U N X 1$ variant status in patients with T-ALL and enabled us to profile variant or 294 wildtype RUNX1 binding using different antibodies. Moreover, our ChIP-seq result indicated that 295 the C-terminal truncating variants p.R232fs and p.Y287* variants actually exhibited a distinct 296 binding pattern than the full-length p.G365R variant and wildtype RUNX1.

297 In summary, we comprehensively described RUNX1 germline variants in childhood ALL. Using 298 multiple functional assays, we identified highly deleterious germline variants in T-ALL and their 299 biochemical and cellular effects. In addition, we characterized somatic genomic alterations 300 associated with RUNX1 germline variation in T-ALL, illustrating the interplay between acquired 301 and inherited genetic variants in the context of leukemia pathogenesis. 
medRxiv preprint doi: https://doi.org/10.1101/2021.04.29.21256340; this version posted May 4, 2021. The copyright holder for this preprint (which was not certified by peer review) is the author/funder, who has granted medRxiv a license to display the preprint in perpetuity.

All rights reserved. No reuse allowed without permission.

\section{Methods}

\section{Patients}

305 A total of 6,190 ALL cases were included for RUNX1 targeted sequencing: 4,132 children with 306 newly diagnosed B-ALL enrolled on the Children's Oncology Group (COG) AALL0232 ( $n=2,224)$, 307 P9904/5/6 $(n=1,634)$, and AALL0331 $(n=274)$ protocols; 704 children with newly diagnosed B308 ALL enrolled on the St.Jude Total XIII and XV protocols; 1,231 children with newly diagnosed T309 ALL enrolled on the COG AALL0434 protocols (1,231); and 123 children with newly diagnosed T310 ALL enrolled on the St.Jude Total XIII and XV protocols (Figure 1A) (36-39). This study was

311 approved by institutional review boards at SJCRH and COG affiliated institutions and informed 312 consent was obtained from parents, guardians, or patients, and assent from patients, as 313 appropriate. Family histories were not available for patients on the COG studies, and thus ALL 314 cases were considered to be sporadic. Germline DNA was extracted from peripheral blood or 315 bone marrow from children with ALL during remission.

316 For targeted RUNX1 sequencing in the sporadic ALL cohort, Illumina dual-indexed libraries were 317 created from the germline DNA of 6,190 children with ALL, and pooled in sets of 96 before 318 hybridization with customized Roche NimbleGene SeqCap EZ probes (Roche, Roche NimbleGen, 319 Madison, WI, USA) to capture the RUNX1 genomic region. Quantitative PCR was used to define 320 the appropriate capture product titer necessary to efficiently populate an Illumina HiSeq 2000 321 flowcell for paired-end $2 \times 100 \mathrm{bp}$ sequencing. Coverage of at least 20 -fold depth was achieved 322 across the targeted RUNX1 locus for $99.2 \%$ of samples. Sequence reads in FASTQ format were 323 mapped and aligned using the Burrows-Wheeler Aligner (BWA)(40, 41), and genetic variants 324 were called using the GATK pipeline (version 3.1)(41), as previously described, and annotated 325 using the ANNOVAR program(42) with the annotation databases including RefSeq(43), 326 Polyphen2(44, 45) and SIFT(46). Non-coding, and synonymous coding variants were excluded 327 from further consideration for this study.

\section{Genomic Analysis of Patient Samples}


medRxiv preprint doi: https://doi.org/10.1101/2021.04.29.21256340; this version posted May 4, 2021. The copyright holder for this preprint (which was not certified by peer review) is the author/funder, who has granted medRxiv a license to display the preprint in perpetuity.

All rights reserved. No reuse allowed without permission.

329 Whole-genome sequencing and RNA sequencing were performed for T-ALL cases with germline

330 RUNX1 variants, whenever available samples were identified. Whole genome seq was done for

331 matched germline and leukemia samples, whereas RNA-seq was done only for leukemia samples.

332 Briefly, DNA was purified using the QIAamp DNA Blood Mini Kit (Qiagen, 51104), and RNA was

333 purified using the RiboPure RNA Purification Kit (Thermo Fisher Scientific, AM1928). DNA (250-

$3341000 \mathrm{ng})$ and RNA (500-1000 ng) was sent to St. Jude Hartwell center for sequencing.

335 Details for functional experiments, leukemia modeling in mouse, genomic analyses, and other 336 experiments can be found in supplemental file.

337 More detailed methods can be found in supplemental files. 
medRxiv preprint doi: https://doi.org/10.1101/2021.04.29.21256340; this version posted May 4, 2021. The copyright holder for this preprint

(which was not certified by peer review) is the author/funder, who has granted medRxiv a license to display the preprint in perpetuity.

All rights reserved. No reuse allowed without permission.

\section{References}

340 1. Churchman ML, Qian M, Te Kronnie G, Zhang R, Yang W, Zhang H, et al. Germline Genetic IKZF1 Variation and Predisposition to Childhood Acute Lymphoblastic Leukemia. Cancer Cell. 2018;33(5):937-48 e8.

2. Trevino LR, Yang W, French D, Hunger SP, Carroll WL, Devidas M, et al. Germline genomic variants associated with childhood acute lymphoblastic leukemia. Nat Genet. 2009;41(9):1001-5.

3. Xu H, Zhang H, Yang W, Yadav R, Morrison AC, Qian M, et al. Inherited coding variants at the CDKN2A locus influence susceptibility to acute lymphoblastic leukaemia in children. Nat Commun. 2015;6:7553.

4. Perez-Andreu V, Roberts KG, Harvey RC, Yang W, Cheng C, Pei D, et al. Inherited GATA3 variants are associated with Ph-like childhood acute lymphoblastic leukemia and risk of relapse. Nat Genet. 2013;45(12):1494-8.

5. Perez-Andreu V, Roberts KG, Xu H, Smith C, Zhang H, Yang W, et al. A genome-wide association study of susceptibility to acute lymphoblastic leukemia in adolescents and young adults. Blood. 2015;125(4):680-6.

6. Papaemmanuil E, Hosking FJ, Vijayakrishnan J, Price A, Olver B, Sheridan E, et al. Loci on $7 \mathrm{p} 12.2,10 \mathrm{q} 21.2$ and 14q11.2 are associated with risk of childhood acute lymphoblastic leukemia. Nat Genet. 2009;41(9):1006-10.

7. Migliorini G, Fiege B, Hosking FJ, Ma Y, Kumar R, Sherborne AL, et al. Variation at 10p12.2 and 10p14 influences risk of childhood B-cell acute lymphoblastic leukemia and phenotype. Blood. 2013;122(19):3298-307.

8. Qian M, Cao X, Devidas M, Yang W, Cheng C, Dai Y, et al. TP53 Germline Variations Influence the Predisposition and Prognosis of B-Cell Acute Lymphoblastic Leukemia in Children. J Clin Oncol. 2018;36(6):591-9.

9. Moriyama T, Metzger ML, Wu G, Nishii R, Qian M, Devidas M, et al. Germline genetic variation in ETV6 and risk of childhood acute lymphoblastic leukaemia: a systematic genetic study. Lancet Oncol. 2015;16(16):1659-66.

10. Wang Q, Stacy T, Binder M, Marin-Padilla M, Sharpe AH, and Speck NA. Disruption of the Cbfa2 gene causes necrosis and hemorrhaging in the central nervous system and blocks definitive hematopoiesis. Proc Natl Acad Sci U S A. 1996;93(8):3444-9.

11. Huang G, Shigesada K, Ito K, Wee HJ, Yokomizo T, and Ito Y. Dimerization with PEBP2beta protects RUNX1/AML1 from ubiquitin-proteasome-mediated degradation. EMBO J. 2001;20(4):723-33.

12. Kanno T, Kanno Y, Chen LF, Ogawa E, Kim WY, and Ito Y. Intrinsic transcriptional activation-inhibition domains of the polyomavirus enhancer binding protein $2 /$ core binding factor alpha subunit revealed in the presence of the beta subunit. Mol Cell Biol. 1998;18(5):2444-54.

13. Owen CJ, Toze CL, Koochin A, Forrest DL, Smith CA, Stevens JM, et al. Five new pedigrees with inherited RUNX1 mutations causing familial platelet disorder with propensity to myeloid malignancy. Blood. 2008;112(12):4639-45.

14. Preudhomme C, Renneville A, Bourdon V, Philippe N, Roche-Lestienne C, Boissel N, et al. High frequency of RUNX1 biallelic alteration in acute myeloid leukemia secondary to familial platelet disorder. Blood. 2009;113(22):5583-7. 
medRxiv preprint doi: https://doi.org/10.1101/2021.04.29.21256340; this version posted May 4, 2021. The copyright holder for this preprint (which was not certified by peer review) is the author/funder, who has granted medRxiv a license to display the preprint in perpetuity.

15. Nishimoto N, Imai Y, Ueda K, Nakagawa M, Shinohara A, Ichikawa M, et al. T cell acute lymphoblastic leukemia arising from familial platelet disorder. Int J Hematol. 2010;92(1):194-7.

16. Song WJ, Sullivan MG, Legare RD, Hutchings S, Tan X, Kufrin D, et al. Haploinsufficiency of CBFA2 causes familial thrombocytopenia with propensity to develop acute myelogenous leukaemia. Nat Genet. 1999;23(2):166-75.

17. Grossmann V, Kern W, Harbich S, Alpermann T, Jeromin S, Schnittger S, et al. Prognostic relevance of RUNX1 mutations in T-cell acute lymphoblastic leukemia. Haematologica. 2011;96(12):1874-7.

18. Brown AL, Arts P, Carmichael CL, Babic M, Dobbins J, Chong CE, et al. RUNX1mutated families show phenotype heterogeneity and a somatic mutation profile unique to germline predisposed AML. Blood Adv. 2020;4(6):1131-44.

19. Huang G, Zhang P, Hirai H, Elf S, Yan X, Chen Z, et al. PU.1 is a major downstream target of AML1 (RUNX1) in adult mouse hematopoiesis. Nat Genet. 2008;40(1):51-60.

20. Matreyek KA, Stephany JJ, and Fowler DM. A platform for functional assessment of large variant libraries in mammalian cells. Nucleic Acids Res. 2017;45(11):e102.

21. Sanda T, Lawton LN, Barrasa MI, Fan ZP, Kohlhammer H, Gutierrez A, et al. Core transcriptional regulatory circuit controlled by the TAL1 complex in human T cell acute lymphoblastic leukemia. Cancer Cell. 2012;22(2):209-21.

22. Liu Y, Easton J, Shao Y, Maciaszek J, Wang Z, Wilkinson MR, et al. The genomic landscape of pediatric and young adult T-lineage acute lymphoblastic leukemia. Nat Genet. 2017;49(8):1211-8.

23. Zhang J, Ding L, Holmfeldt L, Wu G, Heatley SL, Payne-Turner D, et al. The genetic basis of early T-cell precursor acute lymphoblastic leukaemia. Nature. 2012;481(7380):157-63.

24. Michaud J, Wu F, Osato M, Cottles GM, Yanagida M, Asou N, et al. In vitro analyses of known and novel RUNX1/AML1 mutations in dominant familial platelet disorder with predisposition to acute myelogenous leukemia: implications for mechanisms of pathogenesis. Blood. 2002;99(4):1364-72.

25. Antony-Debre I, Duployez N, Bucci M, Geffroy S, Micol JB, Renneville A, et al. Somatic mutations associated with leukemic progression of familial platelet disorder with predisposition to acute myeloid leukemia. Leukemia. 2016;30(4):999-1002.

26. Yoshimi A, Toya T, Kawazu M, Ueno T, Tsukamoto A, Iizuka H, et al. Recurrent CDC25C mutations drive malignant transformation in FPD/AML. Nat Commun. 2014;5:4770.

27. Degryse S, de Bock CE, Cox L, Demeyer S, Gielen O, Mentens N, et al. JAK3 mutants transform hematopoietic cells through JAK1 activation, causing T-cell acute lymphoblastic leukemia in a mouse model. Blood. 2014;124(20):3092-100.

28. Cornejo MG, Kharas MG, Werneck MB, Le Bras S, Moore SA, Ball B, et al. Constitutive JAK3 activation induces lymphoproliferative syndromes in murine bone marrow transplantation models. Blood. 2009;113(12):2746-54.

29. Booth CAG, Barkas N, Neo WH, Boukarabila H, Soilleux EJ, Giotopoulos G, et al. Ezh2 and Runx1 Mutations Collaborate to Initiate Lympho-Myeloid Leukemia in Early Thymic Progenitors. Cancer Cell. 2018;33(2):274-91 e8. 
medRxiv preprint doi: https://doi.org/10.1101/2021.04.29.21256340; this version posted May 4, 2021. The copyright holder for this preprint (which was not certified by peer review) is the author/funder, who has granted medRxiv a license to display the preprint in perpetuity.

30. Wang C, Oshima M, Sato D, Matsui H, Kubota S, Aoyama K, et al. Ezh2 loss propagates hypermethylation at $\mathrm{T}$ cell differentiation-regulating genes to promote leukemic transformation. J Clin Invest. 2018;128(9):3872-86.

31. Connelly JP, Kwon EM, Gao Y, Trivedi NS, Elkahloun AG, Horwitz MS, et al. Targeted correction of RUNX1 mutation in FPD patient-specific induced pluripotent stem cells rescues megakaryopoietic defects. Blood. 2014;124(12):1926-30.

32. Giambra V, Jenkins CR, Wang H, Lam SH, Shevchuk OO, Nemirovsky O, et al. NOTCH1 promotes T cell leukemia-initiating activity by RUNX-mediated regulation of PKC-theta and reactive oxygen species. Nat Med. 2012;18(11):1693-8.

33. Wilkinson AC, Ballabio E, Geng H, North P, Tapia M, Kerry J, et al. RUNX1 is a key target in $\mathrm{t}(4 ; 11)$ leukemias that contributes to gene activation through an AF4-MLL complex interaction. Cell Rep. 2013;3(1):116-27.

34. Gerritsen M, Yi G, Tijchon E, Kuster J, Schuringa JJ, Martens JHA, et al. RUNX1 mutations enhance self-renewal and block granulocytic differentiation in human in vitro models and primary AMLs. Blood Adv. 2019;3(3):320-32.

35. Hyle J, Zhang Y, Wright S, Xu B, Shao Y, Easton J, et al. Acute depletion of CTCF directly affects MYC regulation through loss of enhancer-promoter looping. Nucleic Acids Res. 2019;47(13):6699-713.

36. Larsen EC, Devidas M, Chen S, Salzer WL, Raetz EA, Loh ML, et al. Dexamethasone and High-Dose Methotrexate Improve Outcome for Children and Young Adults With High-Risk B-Acute Lymphoblastic Leukemia: A Report From Children's Oncology Group Study AALL0232. J Clin Oncol. 2016;34(20):2380-8.

37. Bowman WP, Larsen EL, Devidas M, Linda SB, Blach L, Carroll AJ, et al. Augmented therapy improves outcome for pediatric high risk acute lymphocytic leukemia: results of Children's Oncology Group trial P9906. Pediatr Blood Cancer. 2011;57(4):569-77.

38. Pui CH, Sandlund JT, Pei D, Campana D, Rivera GK, Ribeiro RC, et al. Improved outcome for children with acute lymphoblastic leukemia: results of Total Therapy Study XIIIB at St Jude Children's Research Hospital. Blood. 2004;104(9):2690-6.

39. Pui CH, Relling MV, Sandlund JT, Downing JR, Campana D, and Evans WE. Rationale and design of Total Therapy Study XV for newly diagnosed childhood acute lymphoblastic leukemia. Ann Hematol. 2004;83 Suppl 1:S124-6.

40. Li H, and Durbin R. Fast and accurate short read alignment with Burrows-Wheeler transform. Bioinformatics. 2009;25(14):1754-60.

41. McKenna A, Hanna M, Banks E, Sivachenko A, Cibulskis K, Kernytsky A, et al. The Genome Analysis Toolkit: a MapReduce framework for analyzing next-generation DNA sequencing data. Genome Res. 2010;20(9):1297-303.

42. Wang K, Li M, and Hakonarson H. ANNOVAR: functional annotation of genetic variants from high-throughput sequencing data. Nucleic Acids Res. 2010;38(16):e164.

43. Pruitt KD, Brown GR, Hiatt SM, Thibaud-Nissen F, Astashyn A, Ermolaeva O, et al. RefSeq: an update on mammalian reference sequences. Nucleic Acids Res. 2014;42(Database issue):D756-63.

44. Adzhubei IA, Schmidt S, Peshkin L, Ramensky VE, Gerasimova A, Bork P, et al. A method and server for predicting damaging missense mutations. Nat Methods. 2010;7(4):248-9.

45. Adzhubei I, Jordan DM, and Sunyaev SR. Predicting functional effect of human missense mutations using PolyPhen-2. Curr Protoc Hum Genet. 2013; Chapter 7:Unit7 20. 
medRxiv preprint doi: https://doi.org/10.1101/2021.04.29.21256340; this version posted May 4, 2021. The copyright holder for this preprint (which was not certified by peer review) is the author/funder, who has granted medRxiv a license to display the preprint in perpetuity.

All rights reserved. No reuse allowed without permission.

473 46. Kumar P, Henikoff S, and Ng PC. Predicting the effects of coding non-synonymous $474 \quad$ variants on protein function using the SIFT algorithm. Nat Protoc. 2009;4(7):1073-81.

475

476 
medRxiv preprint doi: https://doi.org/10.1101/2021.04.29.21256340; this version posted May 4, 2021. The copyright holder for this preprint (which was not certified by peer review) is the author/funder, who has granted medRxiv a license to display the preprint in perpetuity.

Figure 1

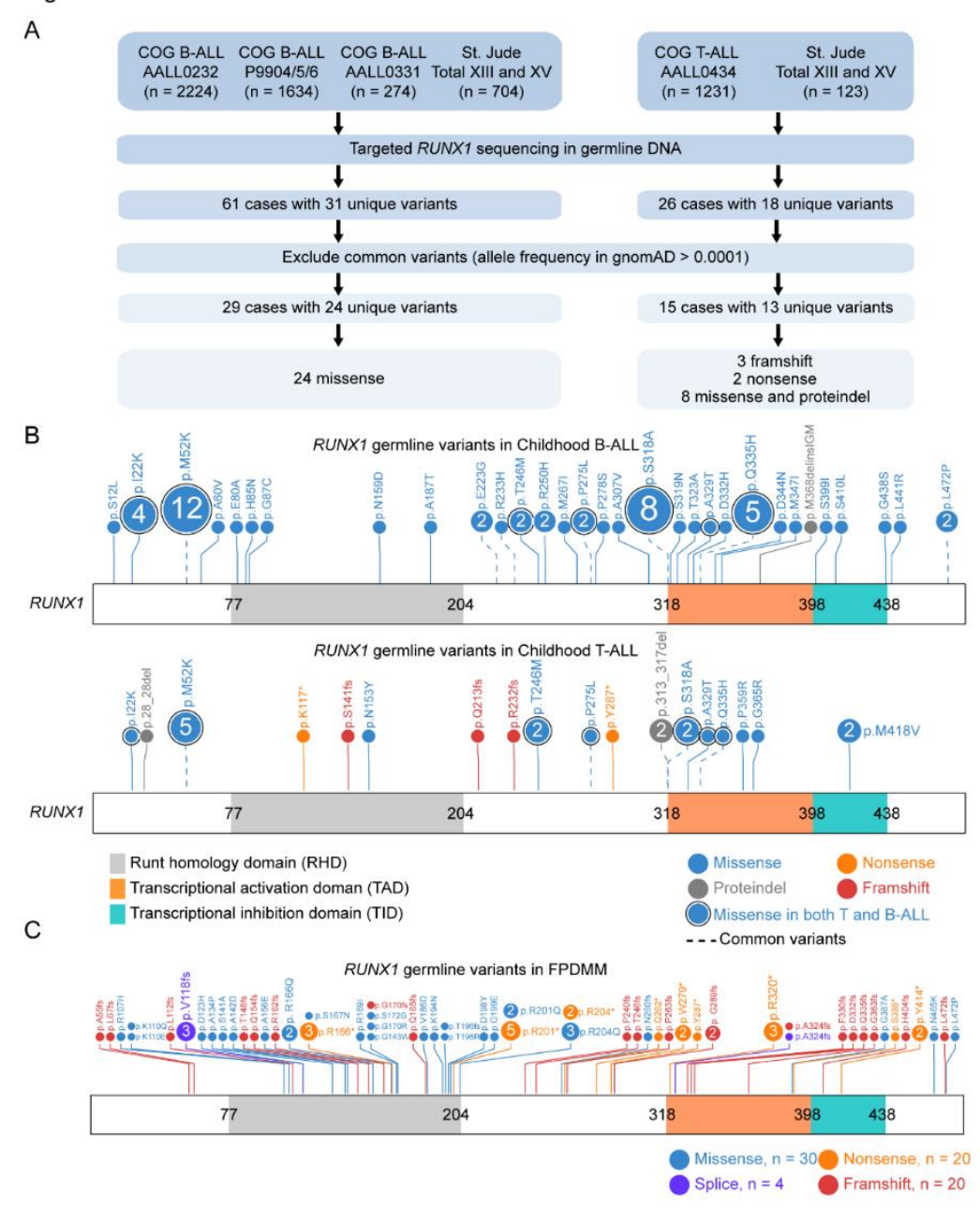

479 Figure 1. Germline RUNX1 variants in childhood B- and T-ALL. (A) CONSORT diagram of

480 the Children's Oncology Group (COG) and St. Jude Children's Research Hospital (St. Jude)

481 patients included in this study. (B) Protein domain plot of RUNX1 and the amino acid

482 substitutions predicted to result from the germline $R U N X 1$ variants identified in this study. The

483 upper panel showed germline RUNX1 variants in B-ALL cases, and the lower panel showed

484 those in T-ALL cases. (C) Protein domain plot of RUNX1 and the germline RUNX1 variants

485 identified previously in familial platelet disorder with associated myeloid malignancy (FPDMM).

486 Data were retrieved from recently published paper (18). 
A

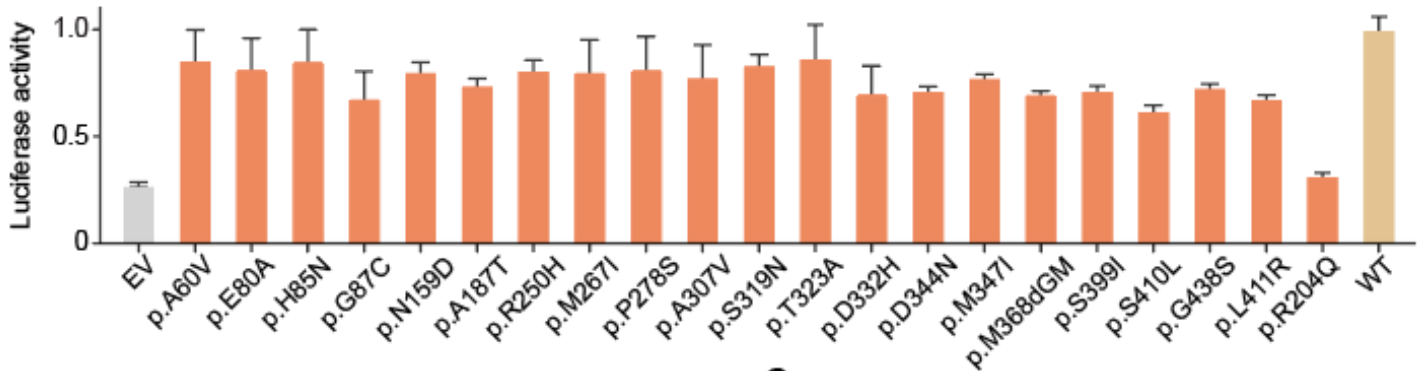

B

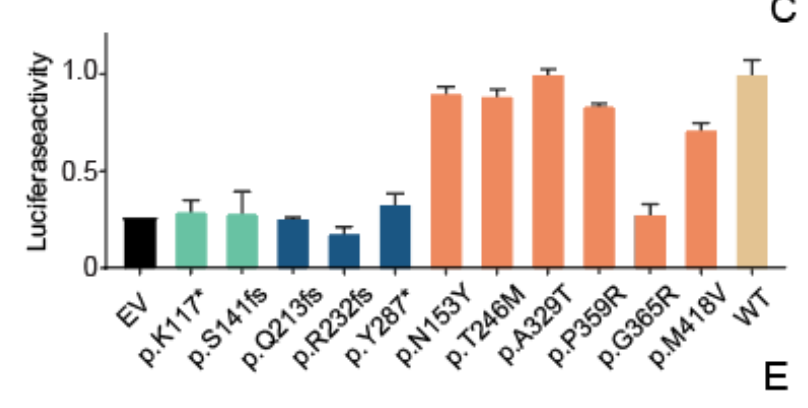

Jurkat cell

$\square$ RUNX1 binding
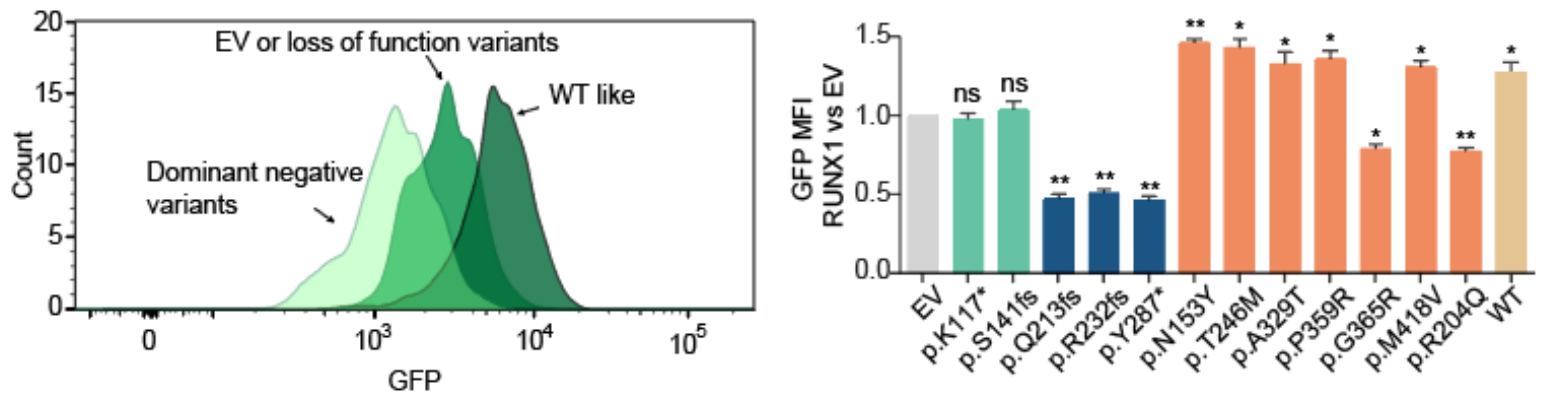

F

(
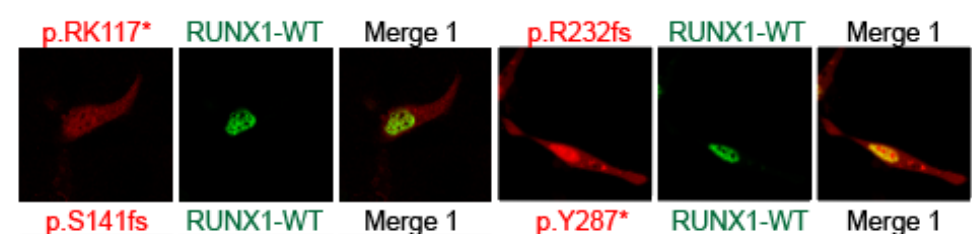

G

RUNX1-WT
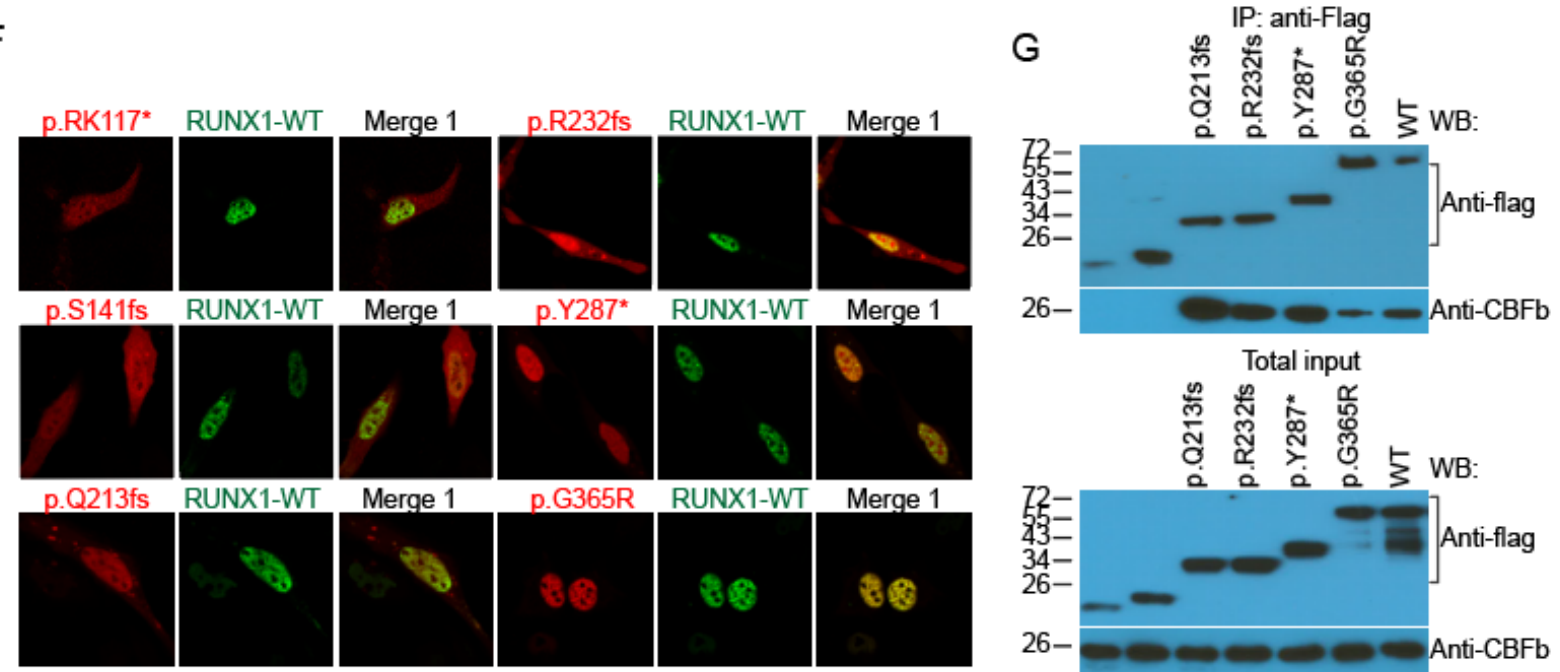

Total input

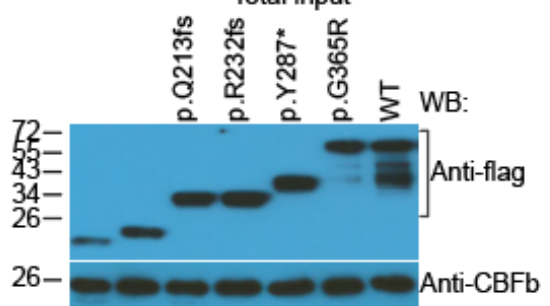

Figure 2. Germline RUNX1 variants influence transcription factor activity, subcellular

489 localization, and CBF $\beta$ interaction. (A) Luciferase reporter gene assay (driven by the PU.1

490 promoter in Hela cells) showed minimal effects on transcription factor activity by missense RUNX1 
medRxiv preprint doi: https://doi.org/10.1101/2021.04.29.21256340; this version posted May 4, 2021. The copyright holder for this preprint (which was not certified by peer review) is the author/funder, who has granted medRxiv a license to display the preprint in perpetuity.

All rights reserved. No reuse allowed without permission.

491 variants identified in B-ALL. (B) By contrast, 6 of 11 RUNX1 variants observed in T-ALL resulted

492 in complete or partial loss of activity, as measured using luciferase reporter gene assay. (C)

493 Design of the Jurkat landing-pad system to measure RUNX1 variant activity in T-ALL. RUNX1

494 (either WT or variant) was inserted at the AAVS locus. EGFP coding sequence was knocked at

495 the 3'-end of GZMA, a RUNX1 target gene. RUNX1 transcription factor activity was determined

496 by flow cytometry of GFP signal which reflects RUNX1-driven GZMA transcription. (D) Flow

497 cytometry analysis of Jurkat cells expressing different RUNX1 variants. Cells harboring dominant

498 negative, loss of function, and WT like RUNX1 variants exhibited the lowest, moderate, and

499 highest GFP signals, respectively. (E) The GFP signal from Jurkat cells expressing each RUNX1

500 variant (relative to empty vector) is shown in bar graph, with error bars indicating

501 standard deviation of triplicates. (F) Immunofluorescence microscopy shows subcellular

502 localization of mCherry-tagged variant proteins and EGFP-tagged WT RUNX1. Variant and WT

503 RUNX1 were fused to mCherry and EGFP and expressed transiently in HEK293T cells, which

504 were then subjected to imaging analyses. (G) Co-immunoprecipitation assay was performed to

505 determine RUNX1-CBF $\beta$ interaction for each deleterious variant. Experiments were performed in

506 HEK293T cells. RUNX1 proteins were pulled down using anti-FLAG antibody and the presence

507 or absence of CBF $\beta$ in the pellet was examined by immunoblotting. 
Figure 3

A

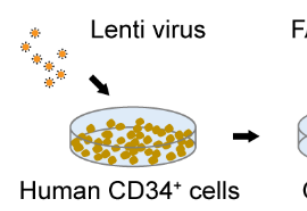

C

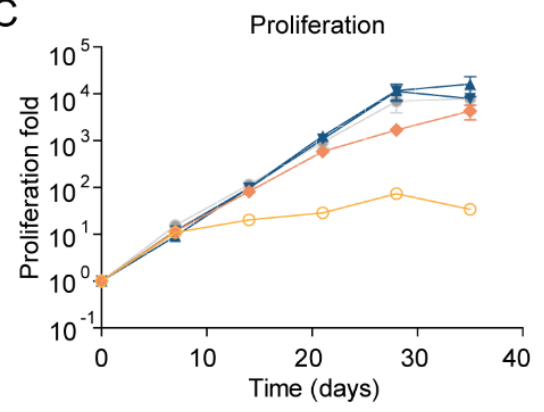

$\mathrm{E}$

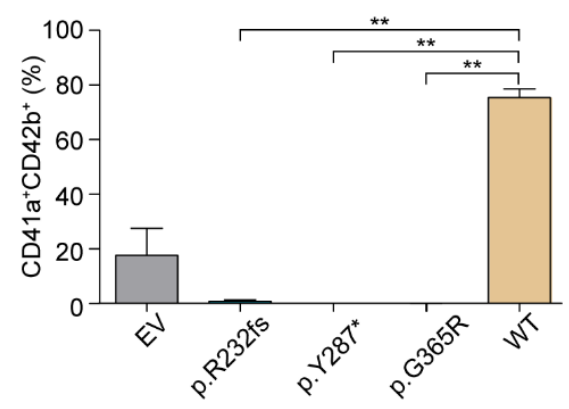

CFU-assay

Proliferation

Apoptosis
Differentiation
B

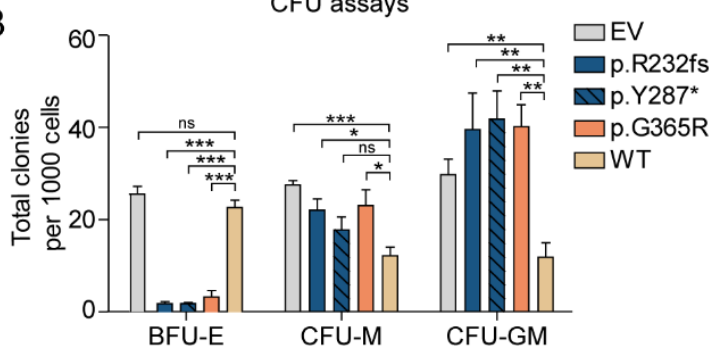

D

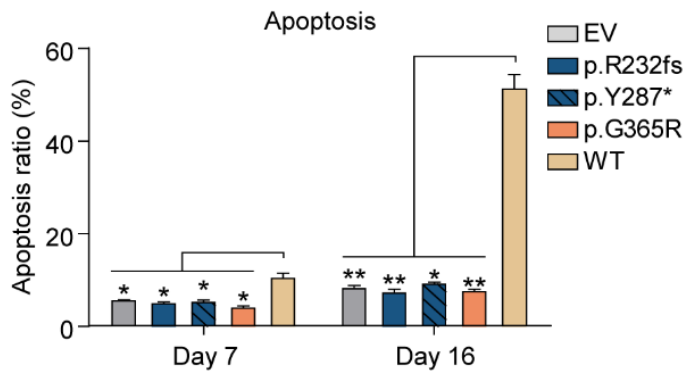

$\mathrm{F}$

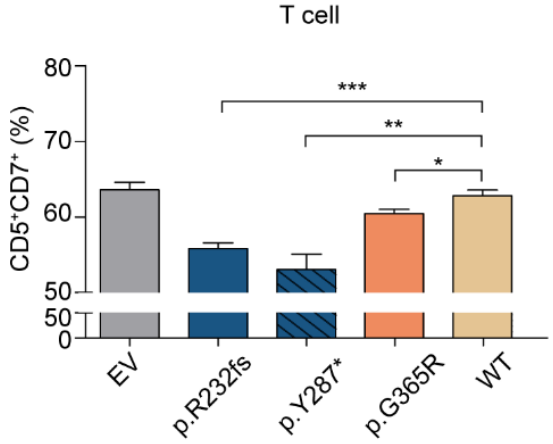

$-\mathrm{EV} * *$

$\rightarrow$ p.R232fs **

$\rightarrow$ p.Y287* ***

$\rightarrow$ p.G365R ***

WT

Figure 3. RUNX1 variants affect in vitro differentiation of human cord blood CD34+ cells.

510 (A) The scheme shows the design of in vitro hematopoietic differentiation assay. RUNX1 variants

511 were lentivirally introduced into human cord blood CD34+ cells. Successfully transduced cells

512 were sorted by flow cytometry and processed for colony forming unit assays, and assessed for

513 cell proliferation and apoptosis, as appropriate. (B) One thousand RUNX1-expressing CD34+

514 cells were plated in MethoCult H4034. The Y-axis shows the count of colonies for each lineage:

515 burst-forming unit erythroid (BFU-E), colony-forming unit-macrophage (CFU-M), and colony-

516 forming unit granulocyte-macrophage (CFU-GM). (C) Proliferation of RUNX1-expressing CD34+

517 cells were monitored for 5 weeks, in Iscove's Modified Dulbecco Medium (IMDM) medium 
medRxiv preprint doi: https://doi.org/10.1101/2021.04.29.21256340; this version posted May 4, 2021. The copyright holder for this preprint (which was not certified by peer review) is the author/funder, who has granted medRxiv a license to display the preprint in perpetuity.

All rights reserved. No reuse allowed without permission.

518 containing 20\% BIT9500, $10 \mathrm{ng} / \mathrm{mL}$ FLT-3 ligand, TPO, SCF, IL-3, and IL-6. The number of cells

519 was counted every week for 5 weeks. (D) Apoptosis of RUNX1-transduced CD34+ cells after 7

520 and 16 days of culture (same culture medium as C) was measured by flow cytometry using

521 Annexin-V and DAPI antibodies. (E-F) CD34+ cells ectopically expressing RUNX1 variants were

522 also subjected to in vitro differentiation assays for megakaryocyte or T cell lineages. Following

523 RUNX1 transduction, cells were cultured in the presence of SFEMII containing megakaryocyte

524 expansion supplement or T-Cell progenitor differentiation supplement for 2 weeks.

525 Megakaryocyte (E) was identified as CD41a+/CD42b+, and T cells (F) were defined as

526 CD5+/CD7+ by flow cytometry. 
medRxiv preprint doi: https://doi.org/10.1101/2021.04.29.21256340; this version posted May 4, 2021. The copyright holder for this preprint (which was not certified by peer review) is the author/funder, who has granted medRxiv a license to display the preprint in perpetuity.

All rights reserved. No reuse allowed without permission.

Figure 4

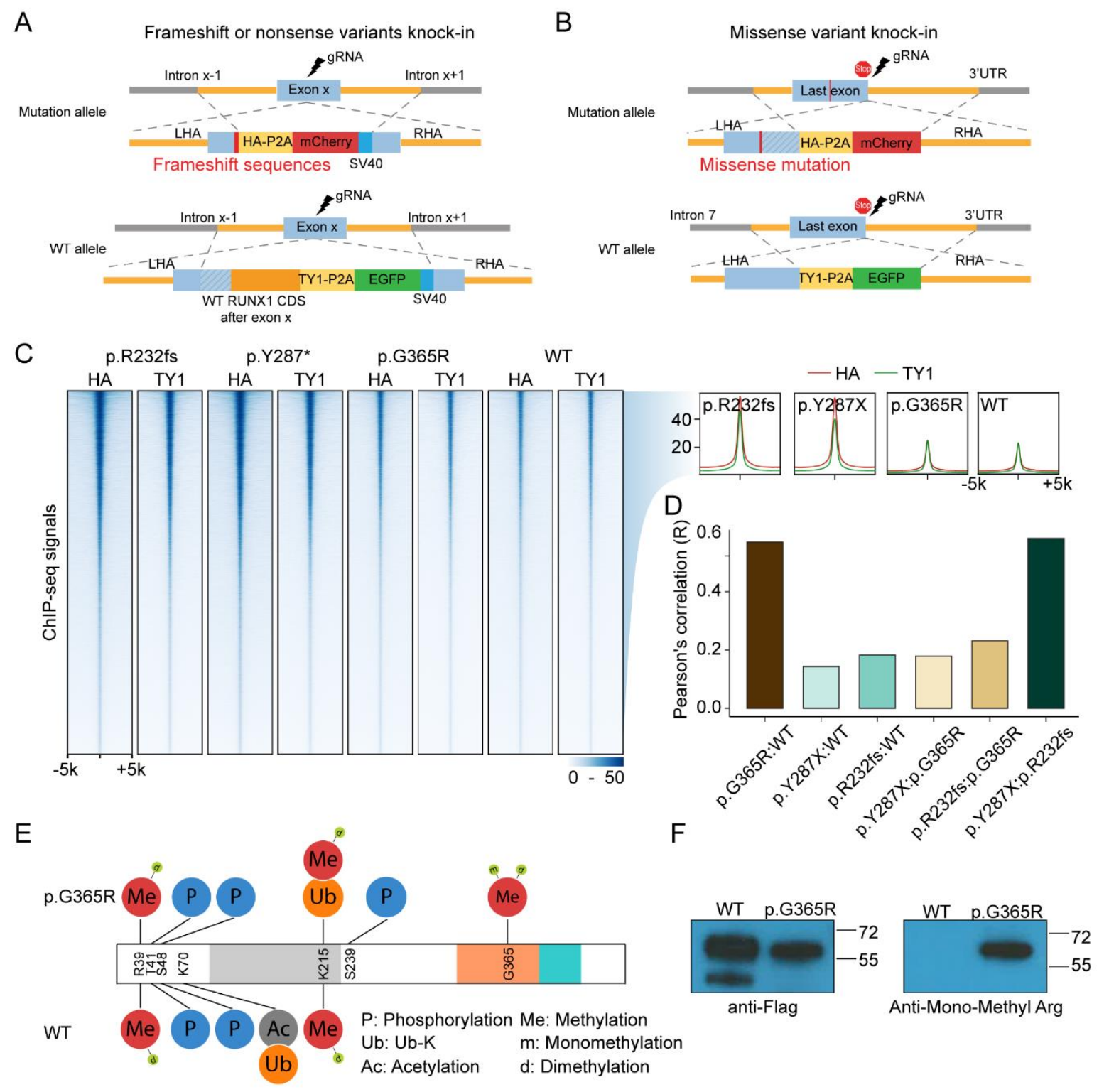

528 Figure 4. RUNX1 variants have highly distinctive DNA binding patterns and associated with

529 altered post-translational modifications. (A-B) Schematic representation of engineered Jurkat

530 cell models for RUNX1 binding profiling studies. Variants (p.R232fs, p.Y287*, and p.G365R) were

531 knocked in using CRISPR-cas9 editing at the endogenous locus in a heterozygous fashion.

532 Meanwhile TY1 and HA epitopes were inserted to the coding sequence of WT and variant RUNX1,

533 respectively. This design enables ChIP-seq of each protein simultaneously using two different

534 antibodies. (C) ChIP-seq using HA antibody (recognizing RUNX1 variant) or TY1 antibody (for 
medRxiv preprint doi: https://doi.org/10.1101/2021.04.29.21256340; this version posted May 4, 2021. The copyright holder for this preprint (which was not certified by peer review) is the author/funder, who has granted medRxiv a license to display the preprint in perpetuity.

All rights reserved. No reuse allowed without permission.

535 wildtype RUNX1) showed that activation domain truncating variant RUNX1 (p.R232fs and

536 p.Y287*) recognized largely identical genomic regions as missense variant p.G365R and wildtype

537 RUNX1. Cells with homozygous WT genotype were used as control. (D) Pearson's correlation of

538 WT and variant RUNX1 ChIP-seq signals (HA divided by TY1). (E) Predicted post translational

539 modification of the p.G365R protein showed arginine methylation resulting from the single

540 nucleotide variant. (F) Arginine mono-methylation was confirmed by immunoblotting using an anti-

541 Mono-Methyl Arginine antibody. 
medRxiv preprint doi: https://doi.org/10.1101/2021.04.29.21256340; this version posted May 4, 2021. The copyright holder for this preprint (which was not certified by peer review) is the author/funder, who has granted medRxiv a license to display the preprint in perpetuity.

All rights reserved. No reuse allowed without permission.

Figure 5

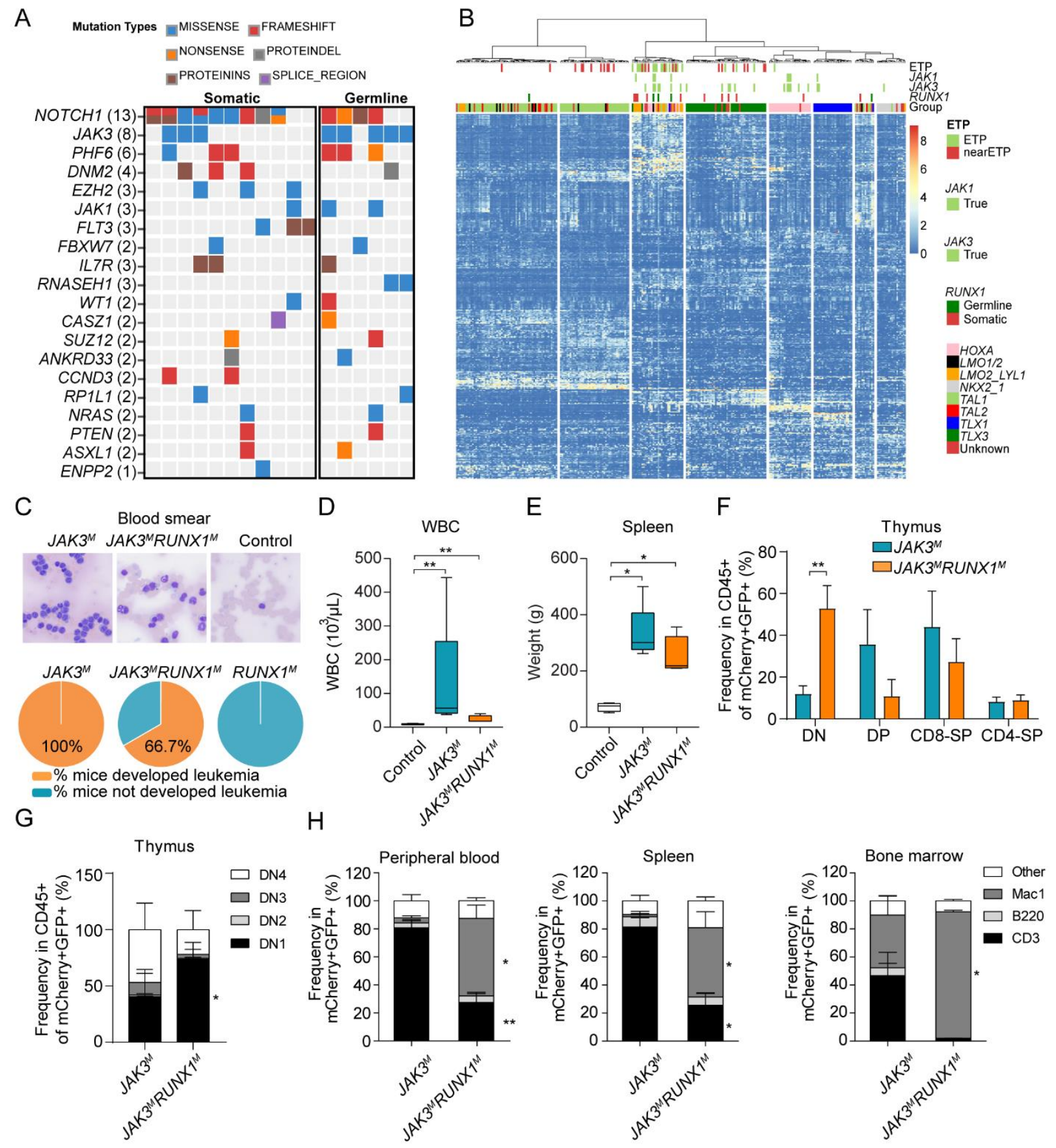

543 Figure 5. Somatic JAK3 mutations co-occurs in T-ALL with germline RUNX1 variants and

544 jointly drive ETP phenotype in mouse models. (A) Somatic JAK3 mutations were significantly

545 enriched in T-ALL cases with germline RUNX1 variants. Whole genome seq of remission samples

546 for 17 T-ALL cases, 6 and 11 with germline variants or somatic mutations in RUNX1, respectively. 
medRxiv preprint doi: https://doi.org/10.1101/2021.04.29.21256340; this version posted May 4, 2021. The copyright holder for this preprint (which was not certified by peer review) is the author/funder, who has granted medRxiv a license to display the preprint in perpetuity. All rights reserved. No reuse allowed without permission.

547 (B) RNA-seq was analyzed for 267 T-ALL cases, including 252, 4, and 11 subjects with WT 548 RUNX1, carrying germline variants or somatic mutations in this gene. Unsupervised clustering 549 shows that RUNX1-variant cases, either germline or somatic, clustered tightly with T-ALL with 550 ETP and near-ETP immunophenotypes. (C) Upper panel: examples of blood smear of JAK3 ${ }^{M}$ and $551 J A K 3^{M} R U N X 1^{M}$ mice at the time of sacrifice, and control mice after 4 months of transplantation. 552 Lower panel: the percentage of mice developed leukemia in each group. JAK3 $: 100 \%, 5$ out of 5535 ; JAK3 ${ }^{M} R U N X 1^{M}: 66.7 \%, 4$ out of 6 . (D) Peripheral leukocyte count of $J A K 3^{M} R U N X 1^{M}(\mathrm{n}=4)$ 554 and $J A K 3^{M}(n=5)$ at the time of sacrifice, and control $(n=7)$ mice after 4 months of transplantation.

555 (E) Spleen weight of $J A K 3^{M} R U N X 1^{M}(\mathrm{n}=4)$, and $J A K 3^{M}(\mathrm{n}=5)$ mice at the time of sacrifice and 556 control mice $(n=4)$ after 4 months of transplantation. ( $F$ and $G)$ Thymocyte immunophenotype of $557 J A K 3^{M}$ and $J A K 3^{M} R U N X 1^{M}$ mice at the time of sacrifice. Co-expression of $R U N X 1^{M}$ and $J A K 3^{M}$ 558 resulted in a drastic increase in DN1 population compared with mice receiving LSK cells 559 expressing JAK3 ${ }^{M}$ only. $(H)$ In peripheral blood, bone marrow, and spleen, $J A K 3^{M} R U N X 1^{M}$ mice 560 showed a significant increase in Mac1+ population and a reduction of the CD3+ population 561 compared to $J A K 3^{M}$ mice. 
medRxiv preprint doi: https://doi.org/10.1101/2021.04.29.21256340; this version posted May 4, 2021. The copyright holder for this preprint

(which was not certified by peer review) is the author/funder, who has granted medRxiv a license to display the preprint in perpetuity.

All rights reserved. No reuse allowed without permission.

\section{Table 1. Germline RUNX1 variants in pediatric ALL cases}

\begin{tabular}{|c|c|c|c|c|c|c|c|c|c|}
\hline Protein (NM 001754) & CHROM & POS & REF & ALT & ExonicFunc.refGene & ALL Subtype ( $n=$ case number) & Allele frequence in gnom $A D$ & Polyphen2_HDIN_pred & SIFT_pred \\
\hline p.L472P & 21 & 36164460 & $A$ & $G$ & missense & B-ALL (2) & $1.99 \mathrm{E}-04$ & Probably damaging & Deleterious \\
\hline p.L441R & 21 & 36164553 & A & c & missense & B-ALL (1) & $7.28 \mathrm{E}-06$ & Probably damaging & Deleterious \\
\hline p.G438S & 21 & 36164563 & c & $\mathrm{T}$ & missense & B-ALL (1) & & Probably damaging & Tolerated \\
\hline p.S410L & 21 & 36164646 & G & A & missense & B-ALL (1) & $1.56 \mathrm{E}-05$ & Probably damaging & Deleterious \\
\hline p. $\$ 3991$ & 21 & 36164679 & c & A & missense & B-ALL (1) & $1.74 \mathrm{E}-05$ & Probably damaging & Deleterious \\
\hline p.M368delinsIGM & 21 & 36164771 & c & :ATGCCC & nonframeshift_insertion & B-ALL (1) & $7.34 \mathrm{E}-05$ & & \\
\hline p.M347| & 21 & 36164834 & c & $T$ & missense & B-ALL (1) & $8.79 E-06$ & Benign & Deleterious \\
\hline p.D344N & 21 & 36164845 & c & $T$ & missense & B-ALL (1) & $6.20 \mathrm{E}-05$ & Probably damaging & Tolerated \\
\hline p.Q335H & 21 & 36164870 & c & A & missense & B-ALL (5) and T-ALL (1) & $1.70 \mathrm{E}-04$ & Probably damaging & Deleterious \\
\hline p.D332H & 21 & 36164881 & c & G & missense & B-ALL (1) & $4.73 \mathrm{E}-06$ & Probably damaging & Deleterious \\
\hline p.A329T & 21 & 36164890 & c & $T$ & missense & B-ALL (1) and T-ALL (1) & & Possibly damaging & Tolerated \\
\hline p.T323A & 21 & 36171598 & $T$ & c & missense & B-ALL (1) & $1.59 \mathrm{E}-05$ & Benign & \\
\hline p.S319N & 21 & 36171609 & c & T & missense & B-ALL $(1)$ & & Possibly damaging & Tolerated \\
\hline p.S318A & 21 & 36171613 & A & c & missense & B-ALL (8) and T-ALL (2) & $8.13 E-04$ & Possibly damaging & Tolerated \\
\hline p.A307V & 21 & 36171645 & G & A & missense & B-ALL (1) & & Possibly damaging & Tolerated \\
\hline p.P278s & 21 & 36171733 & G & A & missense & B-ALL (1) & 1.19E-05 & Possibly damaging & Tolerated \\
\hline p.P275L & 21 & 36171741 & G & A & missense & B-ALL (2) and T-ALL (1) & $2.03 E-04$ & Possibly damaging & Tolerated \\
\hline p.M267I & 21 & 36206711 & c & $T$ & missense & B-ALL (1) & $3.93 \mathrm{E}-05$ & Benign & Tolerated \\
\hline p.R25OH & 21 & 36206763 & c & $\mathrm{T}$ & missense & B-ALL (2) & $3.91 \mathrm{E}-05$ & Probably damaging & Tolerated \\
\hline р.T246M & 21 & 36206775 & G & A & missense & B-ALL (2) and T-ALL (2) & $4.61 \mathrm{E}-05$ & Probably damaging & Tolerated \\
\hline p.R233H & 21 & 36206814 & c & $T$ & missense & B-ALL (1) & $1.67 \mathrm{E}-04$ & Probably damaging & Tolerated \\
\hline p.E223G & 21 & 36206844 & $T$ & c & missense & B-ALL (2) & $1.24 \mathrm{E}-04$ & Probably damaging & Deleterious \\
\hline p.A187T & 21 & 36231825 & c & T & missense & B-ALL (1) & $3.98 \mathrm{E}-06$ & Probably damaging & Deleterious \\
\hline p.N159D & 21 & 36252887 & $T$ & c & missense & B-ALL (1) & & Probably damaging & Deleterious \\
\hline p. $.87 \mathrm{C}$ & 21 & 36259232 & c & A & missense & B-ALL (1) & & Probably damaging & Deleterious \\
\hline p. $\mathrm{H} 85 \mathrm{~N}$ & 21 & 36259238 & G & T & missense & B-ALL (1) & $3.59 \mathrm{E}-05$ & Probably damaging & Deleterious \\
\hline p.E80A & 21 & 36259252 & $T$ & G & missense & B-ALL (1) & $1.22 \mathrm{E}-05$ & Possibly damaging & Deleterious \\
\hline p.A60V & 21 & 36259312 & G & A & missense & B-ALL (1) & $7.40 \mathrm{E}-05$ & Possibly damaging & Tolerated \\
\hline p.M52K & 21 & 36259336 & A & $\mathrm{T}$ & missense & B-ALL (12) and T-ALL (5) & $2.46 \mathrm{E}-04$ & Probably damaging & Deleterious \\
\hline p.122K & 21 & 36265254 & A & $T$ & missense & B-ALL (4) and T-ALL (1) & $4.01 \mathrm{E}-06$ & Benign & Tolerated \\
\hline p.S12L & 21 & 36421162 & G & A & missense & B-ALL (1) & $3.98 \mathrm{E}-06$ & Benign & Tolerated \\
\hline p.M418V & 21 & 36164623 & $T$ & C & missense & T-ALL (2) & & Benign & Deleterious \\
\hline p.G365R & 21 & 36164782 & c & G & missense & T-ALL (1) & $9.73 \mathrm{E}-06$ & Probably damaging & Deleterious \\
\hline p.P359R & 21 & 36164799 & $G$ & c & missense & T-ALL (1) & & Probably damaging & Deleterious \\
\hline p.313_317del & 21 & 36171614 & ITCTGCA & A & nonframeshift_deletion & T-ALL (2) & $1.73 \mathrm{E}-04$ & & \\
\hline p.Y287X & 21 & 36171704 & $G$ & c & stopgain & T-ALL (1) & & & Tolerated \\
\hline p.R232fs & 21 & 36206815 & GC & G & frameshift_deletion & T-ALL (1) & & . & 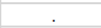 \\
\hline p.Q213fs & 21 & 36206874 & TG & T & frameshift_deletion & T-ALL (1) & & & \\
\hline p.N153Y & 21 & 36252905 & $T$ & A & missense & T-ALL (1) & & Probably damaging & Deleterious \\
\hline p.S141fs & 21 & 36252939 & c & CGGTT & frameshift_insertion & T-ALL (1) & $2.39 \mathrm{E}-05$ & & \\
\hline p.K117X & 21 & 36259142 & $T$ & A & stopgain & T-ALL (1) & & & Tolerated \\
\hline p. $28 \_28$ del & 21 & 36265234 & TAGA & $T$ & nonframeshift_deletion & T-ALL (1) & $4.62 \mathrm{E}-05$ & & \\
\hline
\end{tabular}

564 Polyphen2, Polymorphism Phenotyping v2; SIFT, Sorting Intolerant From Tolerant. 